\title{
DEPOSITIONAL PROCESSES WITHIN THE FRONTAL ICE-CORED MORAINE SYSTEM, RAGNAR GLACIER, SVALBARD
}

\author{
Marek Ewertowski, Leszek Kasprzak, Izabela Szuman, Aleksandra M. TomczyK \\ Adam Mickiewicz University, Institute of Geoecology and Geoinformation, Poznań, Poland \\ Manuscript received January 18, 2010 \\ Revised version March 2, 2010
}

Ewertowski M., Kasprzak L., Szuman I. \& TOMcZYK A.M., 2010: Depositional processes within the frontal icecored moraine system, Ragnar glacier, Svalbard. Quaestiones Geographicae 29(1), Adam Mickiewicz University Press, Poznań 2010, pp. 27-36, Figs 4., Tabs 3. ISBN 978-83-232-2136. ISSN 0137-477X. DOI: 10.2478/v10117-010-0003-8

\begin{abstract}
The marginal zone of the Ragnar glacier has been divided into four zones: ice surface, proglacial lake, lateral moraine and frontal moraine complex. Detailed researches were carried out in the last one - frontal moraine complex consisting of three subzones: (1) outer moraine ridge, (2) culmination moraine ridge and (3) inner moraine plateau. The frontal moraine complex of the Ragnar glacier shows large variability of lithofacies and depositional processes. The aim of this study was to reconstruct the intensity and variability of depositional processes from early stage of the frontal ice-cored moraines creation till present situation. Debris flow processes, glaciofluvial and glaciolacustrine sedimentation as well as aeolian activity and down- and backwasting are identified as most important processes. Intensity of these processes has varied through the time. Presently the frontal ice-cored moraine complex of the Ragnar glacier is relatively stable, except few areas affected by the river or streams.
\end{abstract}

KEYWORDS: ice-cored moraines, depositional processes, sedimentology, Spitsbergen, Arctic

Marek Ewertowski, Leszek Kasprzak, Izabela Szuman, Aleksandra M. Tomczyk, Adam Mickiewicz University, Institute of Geoecology and Geoinformation, Department of Geomorphology, Dzięgielowa 27, 61-680 Poznań, Poland, evert@amu.edu. pl, l.kasp@amu.edu.pl, szuman@amu.edu.pl, alto@amu.edu.pl

\section{Introduction}

Resedimentation processes are one of the most important mechanisms of transformation of glacial environment. Most glacial landforms and sediments are modified to some extent by post-depositional activities. Knowledge of these processes is crucial in the interpretation of sedimentary record of past glaciations (Bennet et al., 2000). Therefore, study of contemporary glacial landsystems is vital for better understanding of Pleistocene features.
This study concentrates on the moraine complex of the mountain, Arctic glacier Raganr. Similar moraine ridges have been described from glaciers on Svalbard (e.g. Klimaszewski, 1960; Boulton, 1967, 1972; Kłysz, 1985; Karczewski, 1989; Stankowski et al., 1989; Huddart \& Hambrey, 1996; Bennet et al., 2000; Etzelmüller, 2000; Lyså \& Lønne, 2001; Sletten et al., 2001; Lønne \& Lyså, 2005; Lukas et al., 2005) as well as from other Arctic areas (e.g. Goldthwait, 1951; Östrem, 1959; Hooke, 1970, 1973; Szupryczyński \& Kozarski, 1970; Evans, 1989; Kjær \& Krüger, 2001). 
The aim of this study was to reconstruct the intensity and variability of depositional processes for high-Arctic Ragnar glacier. The depositional processes were interpreted based on sediments observation within the outcrops and on the surface.

\section{Study Area}

Study area is located near the Petuniabukta (Petunia Bay) in the northern part of the Billefjorden (central part of Spitsbergen) (Fig. 1A). The

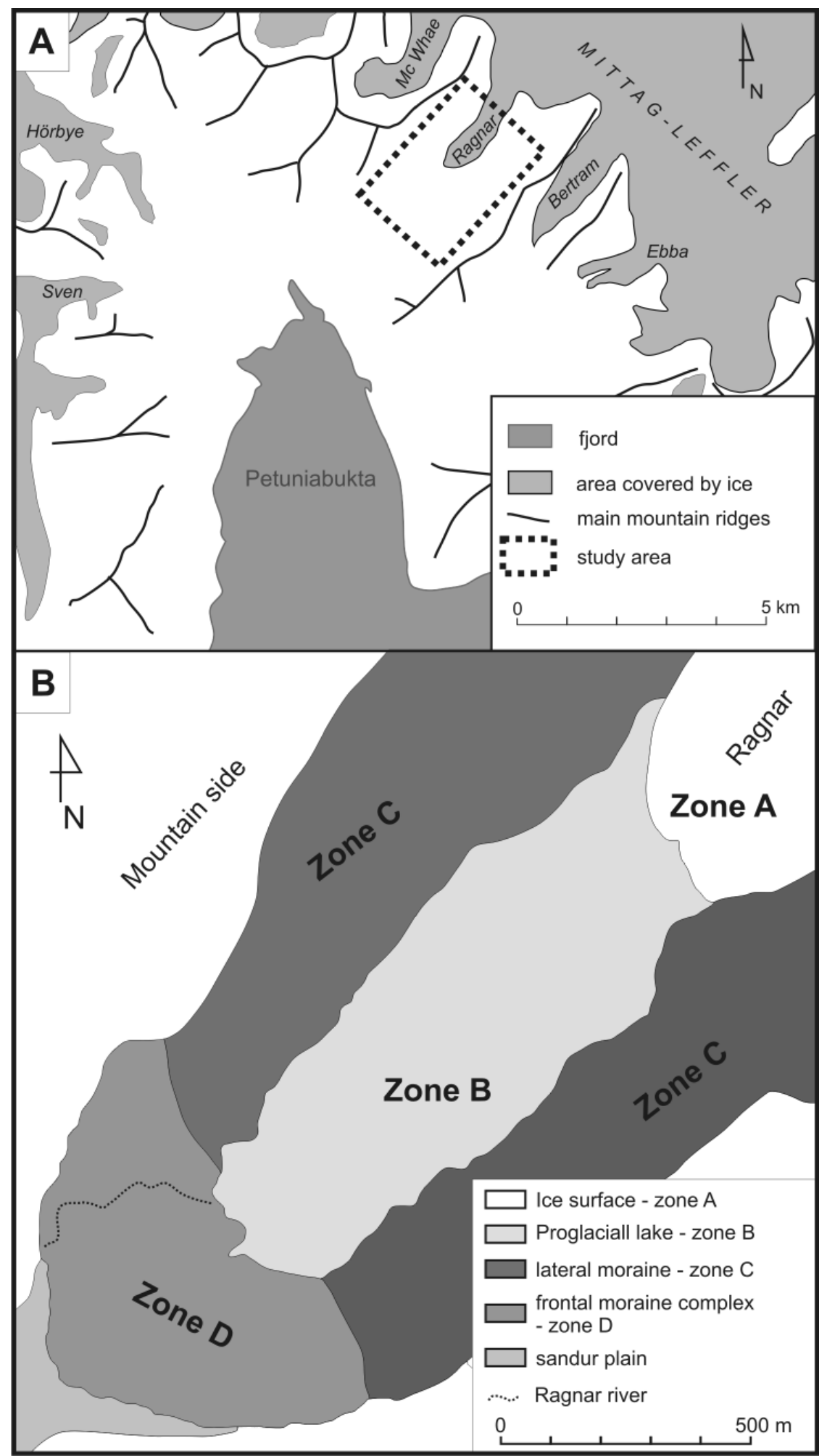

Fig. 1. A - Location of the study area, based on map from Rachlewicz et al. (2007). B - Morphological zones of the Ragnar glacier 
Ragnar glacier is an outlet glacier flowing from the Mittag-Leffler glacier that drains the Lomonosovfonna (Lomonosov ice field). The glacier is $4.9 \mathrm{~km}$ long and covers $6.6 \mathrm{~km}^{2}$. The contemporary ice edge is situated c. $80 \mathrm{~m}$ a.s.l. and is 400 $m$ wide. According to Rachlewicz et al. (2007), its area was reduced by $1.2 \mathrm{~km}^{2}$ between the Little Ice Age (LIA) and 2002, and its ice surface was lowered by $65 \mathrm{~m}$ between 1960 and 2002. The mean flow velocity reaches $3.8-11.1 \mathrm{~m} \mathrm{a}^{-1}$ (Rachlewicz, 2004). The marginal zone of the Ragnar glacier is about $1.5 \mathrm{~km}$ long and $1 \mathrm{~km}$ wide. It was divided into four zones (Fig. 1B) based on geomorphological criteria: (1) frontal moraine complex, (2) lateral moraine complex, (3) proglacial lake and (4) ice surface. In this study we considered only the frontal moraine complex including: the outer and the culmination ridge and also the moraine plateau. Sandur plain was developed in the front of the moraine complex. The large Ragnar river (up to $25 \mathrm{~m}$ wide and $1 \mathrm{~m}$ deep) cuts the frontal moraine complex in the northern part.

\section{Methods}

The sedimentological analyses were done together with a detailed GPS mapping of the icecored moraine complex during the summer seasons 2005 and 2007. The preliminary assessment was based on the geological and geomorphological map (1:40,000, Karczewski et al. 1990) as well as on satellite imagery and aerial photographs which were used to measure the dimension of the main landforms.

Several outcrops were dug to document deposits (Fig. 4). Sedimentological descriptions were done based on lithofacies analysis. Lithofacies is the basic unit used to describe the sediment, depicted by a stratum of defined fabric properties (Miall, 1977; Zieliński, 1993). Fabric can gives information about transport and deposition history of sediments. The lithofacies in this study are defined by code after Miall $(1977,1978)$ and Zieliński (1992, 1995). The upper case letter describes the textural property and lower case letter describes the structural property (Table 1). The glacial diamicton was described with lithofacies code as proposed by Krüger \& Kjær (1999). Diamictons are marked by the D letter. The lower
TABLE 1. Lithofacies CODE SYMBOLS FOR SORTED SEDIMENTS (BASED ON Miall, 1977, 1978) AND ZIELIŃSKI, 1995)

\begin{tabular}{|c|c|}
\hline Symbol & Texture \\
\hline D & diamicton \\
\hline B & boulders \\
\hline G & gravel \\
\hline GS & gravel sandy \\
\hline SG & sand gravely \\
\hline S & fines \\
\hline SF & Structure \\
\hline F & massive \\
\hline Symbol & horizontal lamination, stratification \\
\hline m & wavy lamination \\
\hline h & trough cross-stratification \\
\hline w & ripple cross-lamination of climbing \\
\hline rc & planar cross-stratification \\
\hline p & tronixture \\
\hline $\mathbf{t}$ & \\
\hline
\end{tabular}

TABLE 2. LithofACIES CODE SYMBOLS FOR UNSORTED SEDIMENTS (BASED ON KRÜGER \& KJER, 1999).

\begin{tabular}{|c|c|}
\hline Symbol & \\
\hline $\mathbf{D}$ & diamicton \\
\hline \multicolumn{2}{|c|}{ General apperance } \\
\hline $\mathbf{m}$ & massive \\
\hline $\mathbf{s}$ & stratified \\
\hline \multicolumn{2}{|c|}{ Granulometric composition of matrix } \\
\hline $\mathrm{C}$ & $\begin{array}{l}\text { coarse grained } \\
\text { sandy-gravelly }\end{array}$ \\
\hline $\mathbf{M}$ & $\begin{array}{l}\text { medium-grained matrix, } \\
\text { silt-sandy }\end{array}$ \\
\hline $\mathbf{F}$ & $\begin{array}{l}\text { fine grained, } \\
\text { clayey-silty }\end{array}$ \\
\hline \multicolumn{2}{|c|}{ Clast/matrix relationship } \\
\hline (c) & clast supported \\
\hline$(\mathrm{m} 1)$ & $\begin{array}{l}\text { matrix supported, } \\
\text { clast poor }\end{array}$ \\
\hline$(\mathrm{m} 2)$ & $\begin{array}{l}\text { matrix supported, } \\
\text { clast moderate }\end{array}$ \\
\hline$(\mathrm{m} 3)$ & $\begin{array}{l}\text { matrix supported, } \\
\text { clast rich }\end{array}$ \\
\hline
\end{tabular}


case letter describes the structure of deposits. Next letters characterize the matrix type and matrix to clast relation (Table 2). Additionally, structure of the lithofacies and the contact (gradual, erosive or sharp) between the strata were described.

\section{Deposits and processes within the frontal ice-cored moraine complex}

The frontal ice-cored moraine complex has been described below according to subzones (Fig. 2): (1) outer moraine ridge - subzone I, (2) culmination moraine ridge - subzone II, (3) inner moraine plateau - subzone III.

\section{Subzone I-outer moraine ridge}

Subzone I consists of series of small hillocks and depressions between them. Clast-supported massive diamicton - $\mathrm{DmM}(\mathrm{c})$ is the main lithofacies in the subzone I. Fine-grained material occurs in the hollows - mainly the lithofacies of horizontally or wavy laminated sands and silts (Sh, SFh, Fh). Two inactive debris flows were observed in the subzone I.

Outcrop A - Debris flow deposits (Figs 3B and 3C)

Debris flow deposits are represented by massive diamicton with silty matrix - $\mathrm{DmF}(\mathrm{c})$. A big quantity of coarse clasts (clast-supported diamicton) and lack of segregation suggest that diamictonswere deposited by mass-flow processes. Large amount of fine-grained matrix indicates that cohesion was main force of transport of clasts. This is the type I of flow deposits according to Lawson (1979).

\section{Subzone II - culmination moraine ridge}

Subzone II is the most distinct feature in the frontal moraine complex. The highest hills of the frontal complex occur in the distal part

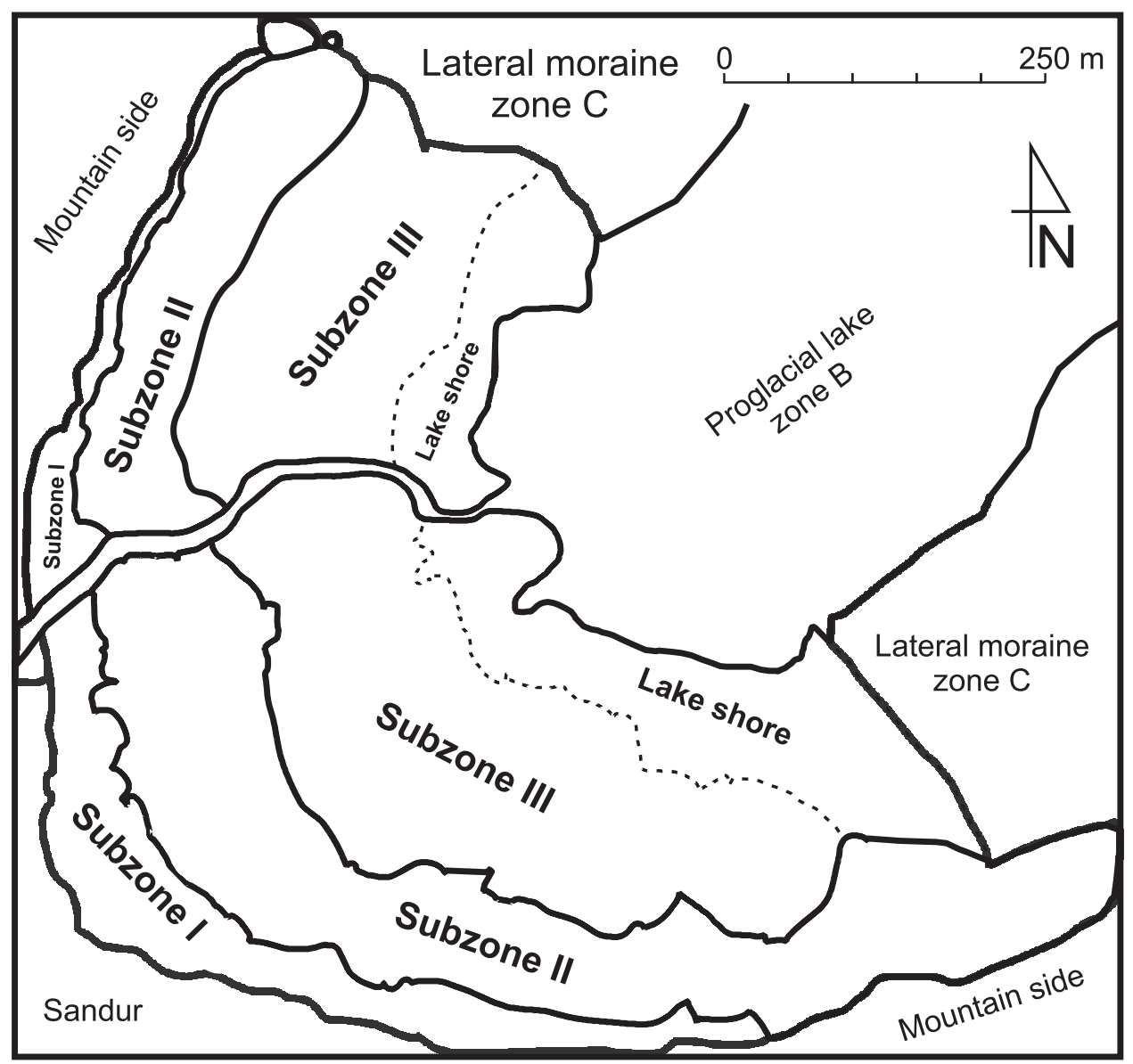

Fig. 2. Subzones of the frontal moraine complex (Zone D on Fig. 1B), Ragnar glacier 


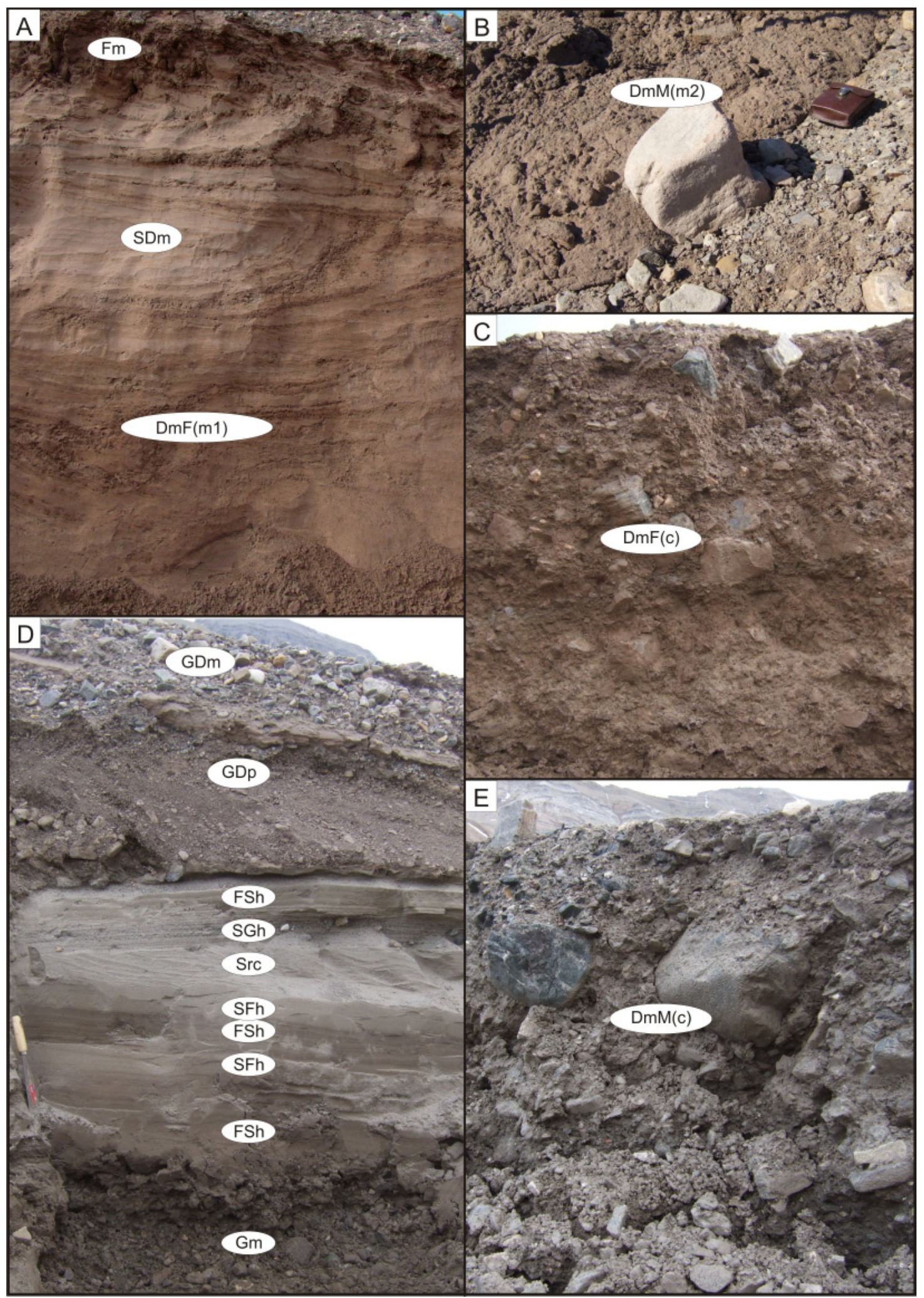

Fig. 3. A - Deformed glaciolacustrine deposits; B - Debris flow deposits with small amount of clasts; C - Debris flow deposits with large amount of clasts and fine-grained matrix; D - Glaciofluvial deposits; E - Debris flow deposits - clast-supported diamicton with medium-grained matrix. (Lithofacies code symbols in Tables 1 and 2) 
(i.e. further from the lake) of this subzone. The hillocks in the inner part (i.e. closer to the lake) are lower. The series of small depressions and hollows are typical for this inner part as well. Some exposures of ice-cores are in the SE part. Hillocks on the culmination ridge are built mainly of lithofacies of massive, matrix-supported diamicton - $\operatorname{DmM}(\mathrm{m} 2)$. Fine grained lithofacies (Sh, SFh, Fh) occur in the hollows. Two exposures in subzone II show mainly debris-flow deposits and fine-grained lacustrine sediments.

\section{Outcrop B - Debris flow deposits (Fig. 3 E)}

The outcrop in the SE part of culmination ridge shows lithofacies of clast-supported, massive diamicton with sandy to silt matrix - $\mathrm{DmM}(\mathrm{c})$. The deposits are compact. Diamicton was deposited by cohesive debris flow (flow type I - Lawson, 1979). Significant thickness and poor sorting suggest short range transport and deposition due to "freezing" - which is confirmed by irregular positioning of the clasts (Zieliński \& van Loon, 1996).

\section{Outcrop C - Glaciolacustrine sediments (fig. 3 A)}

The exposure is located in the middle part of the culmination ridge. Two lithofacies are identified: massive, matrix-supported - $\mathrm{DmF}(\mathrm{m} 1)$ and massive sandy diamicton (SDm), both with poor clasts content. In case of $\mathrm{DmF}(\mathrm{m} 1)$ matrix is fine grained, silty whereas matrix within SDm is mostly medium grained, sandy to silty. Soft sediments deformations visible in the outcrop represent folds and flowage lobes. Both lithofacies $(\mathrm{DmF}(\mathrm{m} 1)$ and $(\mathrm{SDm})$ are characteristic for glaciolacustrine sub-environment with changeable energy of sedimentation. Most likely, the diamictons were previously deposited in horizontal position, within the periodically existed pond. Sandy lithofacies were deposited during the periods of lower transported-energy of stream flowing into the pond. In both cases $(\mathrm{DmF}(\mathrm{m} 1)$ and $\mathrm{SDm})$ the role of water in transport was high, with water content over $25 \%$ (Boulton \& Paul 1967). DmF(m1) lithofacies is much thinner than SDm and occurs in the bottom part. Such features indicate a debris flowage in the early stage of pond filling. Later, the streams energy was decreasing and sandy material was delivered. The fine material (Fm in the top of the exposure) was deposited in one of the latest stages. Fm lithofacies reflects the decantation process and steady-state condition.

The sediments, previously deposited in the depression, presently occur in the top part of the hill. It means that at least one topography inversion took place.

\section{Subzone III - moraine plateau}

Subzone III consists of numerous water ponds and depressions separated by generally low hillocks, but few higher elevated hill also occur. The subzone III contains many fine grained sediments, as a result of glaciolacustrine sedimentation in the ponds. Low hillocks are covered by massive matrix supported diamicton, with low quantity of clasts - DmM(m1).

\section{Outcrop D - glaciofluvial deposits (Fig. 3D)}

One exposure was dug in the northern part of the subzone, near the river bank. Seven lithofacies are recognized in the vertical profile: Lithofacies represent three different groups of sediments: (1) Hyperconcentrated flow deposits - Gm, (2) low/ medium-energy glaciofluvial deposits - FSh, SGh, Src, SFh and (3) high-energy glaciofluvial sediments - GDp, GDm. Each of group reflect separate processes and subenvironments.

\section{Hyperconcentrated flow deposits}

Massive gravel $(\mathrm{Gm})$ with sandy matrix is recognized in the bottom part of the exposure. The contact between lithofacies $\mathrm{Gm}$ and overlying lithofacies of horizontally laminated sands and silts (FSh) is depositional. Lack of sorting and lamination suggest that lithofacies Gm was deposited in the high-energy sub-environment, probably during hyperconcentrated flow.

\section{Low/medium-energy glaciofluvial channel}

1. Two lithofacies of SFh and three of FSh are above the lithofacies $\mathrm{Gm}$.

2. Lithofacies of sand with ripple-cross lamination Src occurs above the second lithofacies of SFh. The angle of ripples climb is $c$. $20^{\circ}$. The contact between Src and lower lithofacies SFh is 
gradual but the contact between Src and higher lithofacies SGh is sharp (erosive).

3. The lithofacies of horizontally stratified gravelly sand (SGh)

Horizontally laminated sands and silts (SFh, $\mathrm{Sh}$ ) and sand with ripple-cross lamination ( $\mathrm{Src})$ point out shallow, low-energy, glaciofluvial channels deposition in lower current regime. Climbing ripples suggest deposits agradation (Jopling \& Walker, 1968). Horizontal lamination of SFh and FSh is probably related to the deposition by low-energy sheet flows (Zielinski \& van Loon 1999, 2000).

Horizontally laminated sand and gravel bed (SGh) represent flow with higher-energy in transitional condition between lower and upper flow regime. SGh as well as SFh and FSh can occur in sheet flows.

\section{High-energy glaciofluvial channel}

GDp, GDm represent high-energy sub-environments. First lithofacies (GDp) is cross-stratified gravel, clast-supported, with coarse grained matrix. Second lithofacies is massive gravel with medium matrix - GDm. Both lithofacies suggest deposition in high-energy, deep glacifluvial channel, where migrating bars occurred. In case of GDp, the transport was probably fast and short within progradation conditions.

\section{Interpretation of sub-environments}

Lithofacies mentioned above represent different processes and sub-environments of deposition (Table 3). Although, at first glance the surface sediments show high disorder, after detailed observation some regularities are noticeable. The coarse grained components (boul-

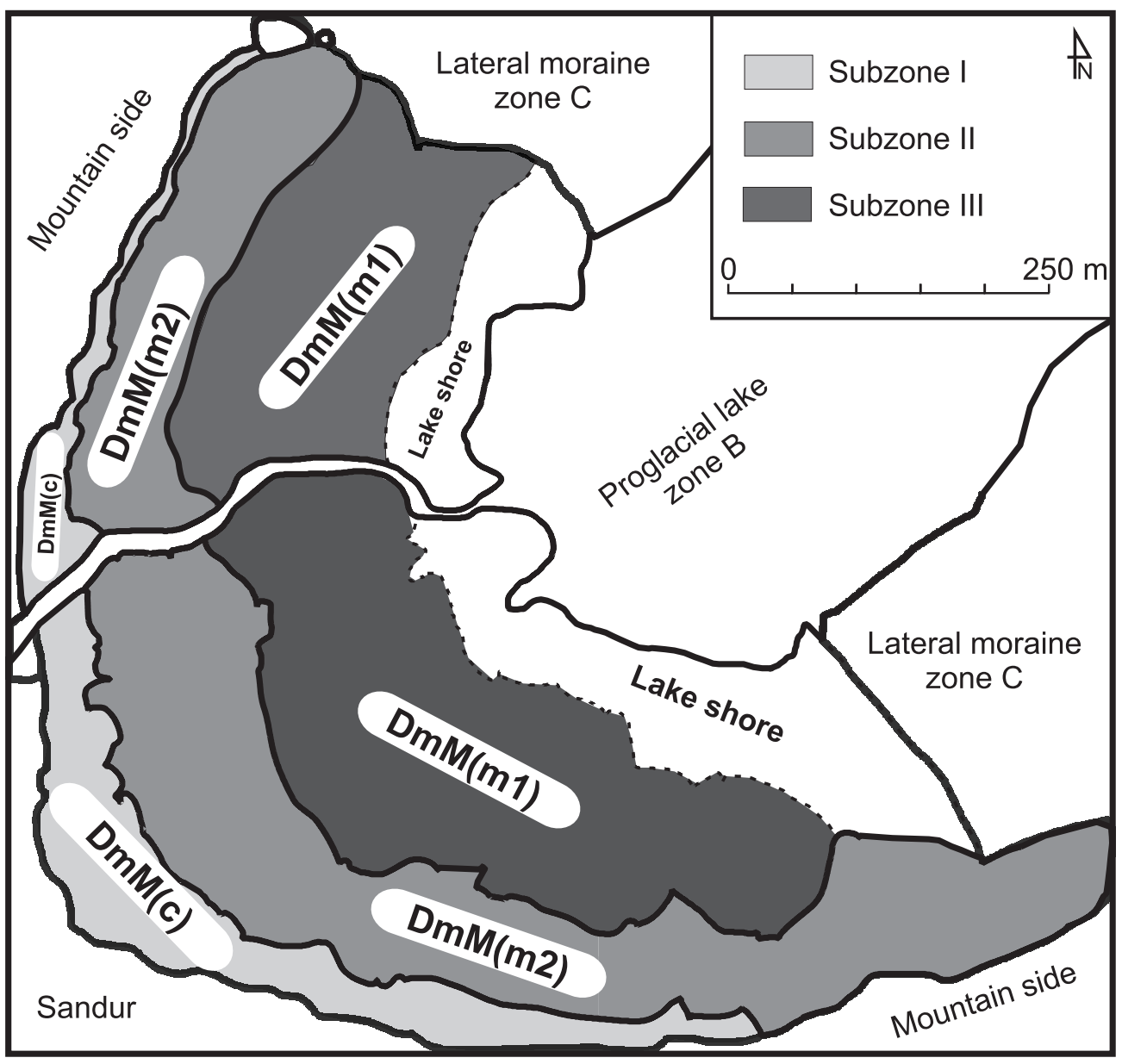

Fig. 4. Distribution of dominated surface sediments within the frontal moraine complex of Ragnar glacier (Zone D on Fig. 1B) 
TABLE. 3. LithOFACIES AND THEIR INTERPRETATION FOR THE FRONTAL MORAINE COMPLEX OF THE RAGNAR GLACIER.

\begin{tabular}{|c|c|c|}
\hline LITHOFACIES & $\begin{array}{l}\text { SUB- } \\
\text {-ENVIRONMENT OF } \\
\text { SEDIMENTS } \\
\text { DEPOSITION }\end{array}$ & INTERPRETATION \\
\hline \multicolumn{3}{|r|}{ Sandy lithofacies } \\
\hline Src & Shallow channels & $\begin{array}{l}\text { 1. current sedimentation } \\
\text { 3. lower regime of flow } \\
\text { 4. low-energy, shallow flow } \\
\text { 5. traction } \\
\text { 6. aggradation with high sediments delivery }\end{array}$ \\
\hline SFh & Shallow channels & $\begin{array}{l}\text { 1. current sedimentation } \\
\text { 2. sheet flows } \\
\text { 3. transitional conditions between lower and upper flow regime } \\
\text { 4. low-energy, shallow flow }\end{array}$ \\
\hline SGh & Channels & $\begin{array}{l}\text { 1. sheet flow } \\
\text { 2. transitional conditions between lower and upper flow regime }\end{array}$ \\
\hline \multicolumn{3}{|r|}{ Silty Facies } \\
\hline Fm & Ponds & 1. decantation \\
\hline FSh & Channels and ponds & $\begin{array}{l}\text { 1. sheet flows } \\
\text { 2. shallow flows } \\
\text { 3. lower regime flow } \\
\text { 4. low-energy flow deposition }\end{array}$ \\
\hline \multicolumn{3}{|r|}{ Diamictons } \\
\hline Dm & Ice-cored moraines & $\begin{array}{l}\text { 1. debris flows } \\
\text { 2. redepositional processes } \\
\text { 3. water content }<25 \%\end{array}$ \\
\hline GDm & $\begin{array}{l}\text { Channels and depres- } \\
\text { sions between ice- } \\
\text { cored moraines }\end{array}$ & $\begin{array}{l}\text { 1. water content }>25 \% \\
\text { 2. the role of excess water in deposition } \\
\text { 3. redepositional processes } \\
\text { 4. hyperconcentrated flow }\end{array}$ \\
\hline SDm & $\begin{array}{l}\text { Ponds and depressions } \\
\text { between ice-cored mo- } \\
\text { raines }\end{array}$ & $\begin{array}{l}\text { 1. water content }>25 \% \\
\text { 2. the role of excess water in deposition } \\
\text { 3. redepositional processes } \\
\text { 4. hyperconcentrated flow }\end{array}$ \\
\hline GDp & Glaciofluvial channels & $\begin{array}{l}\text { 1. progradational deposition } \\
\text { 2. hyperconcentrated flow } \\
\text { 3. low-energy flow deposition }\end{array}$ \\
\hline
\end{tabular}


ders and coarse gravels) are mainly present at the distal part of the frontal moraine complex, on external slopes of the outer moraine ridges. The ratio of fine-grained component to boulder and gravel fraction increases toward the proglacial lake (i.e. to the inner part of frontal moraine complex) (Fig. 4).

\section{The intensity and variability of depositional processes from early stage of the frontal moraine complex formation to present}

Several processes (Table 3) are interpreted as responsible for sediments deposition within the frontal moraine complex of the Ragnar glacier: hyperconcentrated flow, glaciofluvial channelized flow, glaciolacustrine sedimentation and debris flows. Lawson (1979) estimated that $95 \%$ of deposits present at the Manatuska glacier marginal zone were redeposited. The similar can be observed in case of the Raganr glacier. Debris flows dominated in the early stage of the frontal moraine complex development, but now the ice-cores are isolated by thick, up to $2 \mathrm{~m}$, debris cover and only in few points of the frontal moraine complex the ice is exposed. The thick debris cover slowed down the downwasting and backwasting processes.

The fluvial processes probably were and still are mostly limited to the river banks and periodical streams. However, the role of fluvial sedimentation was higher in the early stage of the frontal moraine complex creation, probably due to more intense ice-cores melting, generating large amount of meltwater. Glaciolacustrine sedimentation was also more intense in the past, because presently the considered area is relatively dry. Therefore, only few water-filled ponds occur. It is also thought that the aeolian activity plays restricted role in sediments transformation with similar intensity from past till now. Occurrence of the glaciolacustrine deposits in topographic heights suggests that the intense sedimentation and resedimentation processes caused at least one topographic inversion.

Generally, in case of frontal moraine complex of the Ragnar glacier, most of the sediments are resedimented within the marginal zone and do not transferred outside to proglacial system.

\section{Conclusions}

Presently the frontal ice-cored moraine complex is relatively stable and small quantity of debris undergo displacement. The intensive resedimentation is restricted to few areas: affected by river activity and some parts of steep ridges with directly exposed ice-cores, where the mass movement processes occur with high intensity. Except these areas the thick debris cover isolates the icecores from melting.

Resedimentation processes were the main factor influencing on the morphology and sediments distribution in the early stage of the icecored moraine complex creation as well as nowadays. But the intensity of gravity flows is much lower now. The high vertical diversification within lithofacies suggests the high ratio of subenvironmental transformation during the time. The glacolacustrine and glaciofluvial processes are suggested to be less important now than in the early stage of the frontal moraine complex development. In case of aeolian activity, their role is relatively stable from the LIA till now, but the facies reflecting the aeolian processes activity are hard to be identified because of still higher role of mass movement, fluvial and lacustrine processes.

\section{Acknowledgements}

The fieldwork was financially supported by the Polish National Committee on Scientific Research (KBN) (Grant No. 6 PO4E 041 21, Grant No. 2 P04G 040 28) and Polish Ministry of Science and Higher Education (Grant No. 3505/P01/2007/32). Members of the Adam Mickiewicz University expeditions to Svalbard in years 2005 and 2007 helped with the fieldwork. To all these institutions and persons we extend our sincere thanks. M. Ewertowski was supported by Kulczyk Foundation fellowship.

\section{References}

Bennet M.R., Huddart D., Glasser N.F. \& Hambrey M.J., 2000. Resedimentation of debris on an ice-cored lateral moraine in the high-Arctic (Kongsvegen, Svalbard). Geomorphology 35: DOI: 21-40. 101144/gsjgs.154.4.0623. 
Boulton G.S., 1967. The development of a complex supraglacial moraine at the margin of Sørbreen, Ny Friesland, Vestspitsbergen glaciers. Journal of Glaciology 6: 717-736.

Boulton G.S., 1972. Modern Arctic glaciers as depositional models for former ice sheets. Journal of the Geological Society of London 128: 361-393.

Boulton G.S. \& PAul M.A., 1976. The influence of genetic processes on some geotechnical properties of glacial tills. Quarterly Journal of Engineering Geology and Hydrogeology 9: 159-194.

Evans D.J.A., 1989. Apron entrainment at the margins of sub-polar glaciers, north-west Ellesmere Island, Canadian High Arctic. Journal of Glaciology 35: 317-324. DOI: 10.1016/j.quascirev.2008.10.024.

ETZELMÜLLER B,. 2000. Quantification of thermo-erosion in pro-glacial areas - Examples from Spitsbergen. Zeitschrift für Geomorphologie 44: 343-361.

Goldthwait R.P, 1951. Development of end moraines in east-central Baffin Island. Journal of Geology 59: 567-577.

HoOKe R.LeB., 1970. Morphology of the ice-sheet margin near Thule, Greenland. Journal of Glaciology 9: 303-324.

HoOKe R.LeB., 1973. Flow near the margin of the Barnes ice cap and the development of ice cored moraines. Bulletin of the Geological Society of America 84: 3929-3948.

Hudart D. \& Hambrey M.J., 1996. Sedimentary and tectonic development of a high-arctic, thrust-moraine complex: Comfortlessbreen, Svalbard. Boreas 25: 227-243.

JOPLING A.V. \& WALKER R.G., 1968. Morphology and origin of ripple-drift cross-lamination, with examples from the Pleistocene of Massachusetts. Journal of Sedimentary Research 4: 971-984.

KARCZEWSKI A., 1989. The development of the marginal zone of the Hörbyebreen, Petuniabukta, central Spitsbergen. Polish Polar Research 10: 371-377.

Karczewski A. (ed.), BorówKa M., Gonera P., KasprzaK L., KŁysz P., KostrzeWSKI A., Lindner L., Marks L., RygielsKi W., StANKOWSKI W., WojCIECHOWSKI A. \& WYSOKIŃSKI L., 1990. Geomorphology - Petuniabukta, Billefjorden, Spitsbergen, 1:40 000. Uniwersytet im. A. Mickiewicza, Poznań.

KJÆR K.H. \& KRÜGER J., 2001. The final phase of dead-ice moraine development: processes and sediment architecture, Kötnojökull, Iceland. Sedimentology 48: 935-952.

KuIMASZEWSKI M., 1960. Studia geomorfologiczne w zachodniej części Spitsbergenu między Kongsfjordem a Eidembuktą. Prace Geograficzne Uniwersytetu Jagiellońskiego, Kraków, 23: 166 pp.

KŁYsZ P., 1985. Glacial forms and deposits of Ebba Glacier and its foreland (Petuniabukta region, Spitsbergen). Polish Polar Research 6: 283-299.

KRÜGER J. \& KJÆR K.H., 1999. A data chart for field description and genetic interpretation of glacial diamicts and associated sediments - with examples from Greenland, Iceland, and Denmark. Boreas 28: 386-402.

LAWSON D.E., 1979. Sedimentological analysis of the western terminus region of the Matanuska Glacier, Alaska. US Army CREEL Report 79, 9, New Hampshire, Hannover: $112 \mathrm{pp}$.

LøNNE A. \& LYSÅ I., 2005. Deglaciation dynamics following the Little Ice Age on Svalbard: Implications for shap- ing of landscapes at high latitudes. Geomorphology 72: 300-319.

LYSÅ I. \& LøNNE A., 2001. Moraine development at a small high-Arctic valley glacier: Rieperbreen, Svalbard. Journal of Quaternary Science 16: 519-529. DOI: 10.1002/jqs.613.

LuKas S., Nicholson L.I., Ross F.H. \& Humlum O., 2005. Formation, meltout processes and landscape alteration of high-Arctic ice-cored moraines: examples from Nordenskiold Land, Central Spitsbergen. Polar Geography 29(3): 157-187. DOI: 10.1080/789610198.

Miall A.D., 1977. A review of the braided river depositional environment. Earth Science Review 13: 1-62.

Miall A.D., 1978. Lithofacies types and vertical profile models in braided river deposits: a summary. In: A.D. Miall (ed.), Fluvial sedimentology. Canadian Society of Petroleum Geologists 5: 597-604.

Östrem G., 1959. Ice melting under a thin layer of moraine and the existence of ice cores in moraine ridges. Geografiska Annaler 41A: 228-230.

Rachlewicz G., 2004. Pomiary ruchu lodowców w otoczeniu Petuniabukta - Billefjorden (Spitsbergen Środkowy). XXX Międzynarodowe Sympozjum Polarne, streszczenia wystapien, Gdynia: 149.

Rachlewicz G., Szczuciński W. \& Ewertowski M., 2007. Post - "Little Ice Age" retreat rate of glaciers around Billefjorden in central Spitsbergen, Svalbard. Polish Polar Research 28: 159-186.

SLetTen K., LySÅ A. \& LøNNE I., 2001. Formation and disintegration of a modern high-arctic ice-contact system, Scott Turnerbreen, Svalbard. Boreas 30: 272-284.

Stankowski W., KasprzaK L., KostrZewski A. \& Rygielski W., 1989. An outline of morphogenesis of the region between Hörbyedalen and Ebbadalen, Petuniabukta, Billefjorden, central Spitsbergen. Polish Polar Research 10: 267-276.

SZUPRYCZYŃSKI J. \& KOZARSKI S., 1970. Relief of the marginal zone of Sidujökull (Iceland). Bulletin de l'Academie Polonaise des Sciences, sér. géologie et géographie 18: 269-278.

ZiELIŃSKI T., 1992. Moreny czołowe Polski pótnocno-wschodniejosady i warunki sedymentacji. Uniwersytet Śląski, Katowice: $95 \mathrm{pp}$.

ZieLIŃSKI T., 1993. Sandry Polski pótnocno-wschodniej-osady $i$ warunki sedymentacji. Uniwersytet Śląski, Katowice: $96 \mathrm{pp}$.

ZIELIŃSKI T., 1995. Kod litofacjalny i litogenetyczny - konstrukcja i zastosowanie. In: E. Mycielska-Dowgiałło \& J. Rutkowski (eds.), Badania osadów czwartorzędowych. Uniwersytet Warszawski, Warszawa: 220-235.

ZIELIŃSKI T. \& VAN LoON A.J., 1996. Characteristics and genesis of moraine-derived flowtill varieties. Sedimentary Geology 101: 119-143.

ZIELINSKI T. \& VAN LOON A.J., 1999. Subaerial terminoglacial fans II: a semi-quantitative sedimentological analysis of the middle and distal environments. Geologie en Mijnbouw 78: 73-85.

ZIELINSKI T. \& VAN LOON A.J., 2000. Subaerial terminoglacial fans III: a semi-quantitative sedimentological analysis of the middle and distal environments. Geologie en Mijnbouw 79: 93-107. 